\title{
Post-consumer wood in environmental decision-support tools ${ }^{1}$
}

\author{
Frank Werner, Hans-jorg Althaus und Klaus Richter
}

Keywords: Wood, recycling; decision-support tool; post-consumer wood;

life cycle assessment (LCA); material flow analysis (MFA). FDK 839: UDK 504.064.2.003.3

\begin{abstract}
Environmental decision-support tools, such as life cycle assessment or material flow analysis, only support the decision-making process if, in addition to the causalities of the systems under study, their role within sustainable development is adequately depicted. This article outlines the basis of the two requirements for post-consumer wood in Switzerland.
\end{abstract}

Abstract: Umweltbezogene Entscheidungsinstrumente wie Ökobilanzen und Stoffstrom-Modelle dienen der Entscheidungsfindung nur dann, wenn es gelingt, die Kausalitäten der betrachteten Systeme sowie deren Rolle für die nachhal. tige Entwicklung adäquat abzubilden. Der Artikel umreisst dies für das Thema Altholz in der Schweiz.

\section{Introduction}

Over recent years, modelling within the framework of decision-support tools such as life cycle assessment (LCA) (table 1) or material flow analysis (MFA) (table 2) has become a widespread approach for environmentally conscious decision-making. The validity of models set up within the methodological framework of these tools - as well as its acceptance by the decision-makers - strongly depend on the capability of the modeller to adequately depict the material and market characteristics of the materials and products under investigation (HOFstetter et al. 2000; Werner 2002). Dependent on that, the logic of rational planning and management by the different decision-makers involved have to be properly addressed. The accuracy and suitability of the description of the material and $\bar{\Xi}$ market characteristics as well as the proper addressing of the logics of rational planning and management are the final arbiter on any methodological decision during modelling in decision-support tools.

This article provides a description of the current environmental discussion of wood "from cradle to grave", on which methodological decisions during the modelling in decisionsupport tools can be based. We outline the current situation and potential use options of wood - particularly post-consumer wood in Switzerland - and discuss wood flow politics in the light of sustainable development. Further on, this article contains an extensive review of recent literature on wood in the environmental discussion with emphasis on sustainable use options of post-consumer wood in Switzerland.

\section{Some characteristics of wood and wood industry}

Wood is the world's most important renewable material and regenerative fuel (BOWYER 1995; SCHULz 1993; SUTTON 1993; ELDAG 1980: 105; FrüHWALD et al. 2001). Like stone, wood has been used for building since prehistoric times but also as fuel and is therefore deeply rooted in our entire history of civilisation. Today, wood is utilised in many forms, for example, sawn wood, particleboard, plywood, fibreboard and veneer. Its main applications are construction material for housing and civil engineering, furniture, railway ties (sleepers), poles and

1 This article is a result of the COST Action E9 (1997-2001) "Life cycle assessment of forestry and forest products". reinforcement for mining. Even today wood is still one of the leading construction materiais.

Wood is also an important raw material for the pulp and paper industry and plays a significant role in the packaging sector.

Wood can be used as solid wood, or as particles, fibres or even as chemicals on a molecular basis. The material characteristics and the twofold nature of wood as material and fuel allow an almost $100 \%$ utilisation of this resource (KORHONEN et al. 2001).

Wood's properties are anisotropic and inhomogeneous; they vary from tree to tree and even within the same log. Using suitable technologies anisotropy can be reduced in wood panels and engineered wood products. And even though wood is one of the oldest materials used by humankind, numerous new developments have taken place in recent years, which have broadened the application of wood and wood products. Especially noteworthy are new impregnation techniques and combinations with other materials such as plastics and metals. The main advantages of wood lie in its relatively low price, favourable strength-to-weight ratio, its vapour permeability, its appealing, individual appearance, and in the ease in which it is worked with proven techniques (SCHULz 1972).

As a biogenic material wood is subject to biological and photochemical degradation and, in consequence, (outdoor) applications may require regular constructive and/or chemical wood protection. Its hygroscopic nature leads to changes in dimension ("swelling and shrinking") depending on the humidity of the environment. This can lead to deformation and shakes if wood is not applied in a carefully considered way.

Reuse and recycling of wood as material must always be considered to be downcycling (except reuse in a very strict sense), as diameters of wood pieces and fibie length decrease while "unwanted" contaminants (e.g., from wood treatment or coating) increase with each processing step (WILLEITNER \& BUCKI 1994). The more often wood is reprocessed, the more restricted are its potential applications. Original properties can only be restored with the investment of (non-renewable) energy and material (FraANJE 1997).

Wood as a naturally grown material, irregular in shape and structure, is not, a priori, suitable for industrial processing or use in technical applications. As a consequence, the management and processing of wood generates a variety of co-products over the wood chain: from its cultivation in managed forests, its extraction, sawing, and processing to intermediate and finished products on to its recycling, incineration or final 
Table 1: Life Cycle Assessment.

Tabelle 1: Ökobilanzen.

\section{Life Cycle Assessment}

Life Cycle Assessment (LCA) is a decision-support tool assessing the environmental aspects and potential impacts associated with a product, by:

- compiling an inventory of relevant inputs and outputs of a product stemming from resource extraction, production, use/consumption, and recycling or final disposal;

- evaluating the potential environmental impacts associated with those inputs and outputs;

- interpreting the results of the inventory analysis and the impact assessment phases in relation to the objectives of the study.

The general categories of environmental impact that must be considered include resource use, human health, and ecological consequences.

LCA can assist in:

- identifying opportunities to improve the environmental aspects of products at various points in their life cycle;

- strategic decision-making in industry, governmental or nongovernmental organisations;

- selection of relevant indicators of environmental performance;

- marketing.

General literature: GUINNÉE et al. (2001), series of standards 150 14040.

Wood-specific literature: JungmeIer et al. (2002); Werner et al. (1999), Werner (2001); Frühwald et al. (1996); Frühwald et al. (2000).

Table 2: Material Flux Analysis.

Tabelle 2: Stoffstrommodelle.

\section{Material Flux Analysis}

The overall objectives of the Material Flux Analysis (MFA) are to understand an anthropospheric system by identifying environmentally and economically relevant energy and material flows in order to account for the material fluxes of the investigated system. MFA is a system description tool that does not give a formal evaluation. MFA is often described using the metaphor that the material fluxes represent the metabolism of the system. The basic descriptive elements of MFA are "stocks", "flows", "sources" and "sinks".

The main questions which SFA addresses are:

- Which material fluxes are relevant and substantial for a system?

- Which fluxes and stocks can be used as indicators for sustainability, what are the requirements and are they fulfilled?

Closely related to MFA is Substance Flow Analysis (SFA). SFA focuses on single elements, such as nitrogen, cadmium or carbon dioxide, whereas MFA investigates total mass or energy or bulk material.

General literature: BACCINI \& BRUNNER (1991).

Wood-specific literature: Lafleur \& fraanje (1997); Müllek (1998). disposal. Co-products generated are, e.g., residues from thinning, bark, sawdust, shavings, chips and fibres, side-cuts and wood waste, and waste of intermediate products from wood and wood-based industry.

If co-products cannot be used internally, e.g. for the generation of thermal energy for wood drying, they can be sold to other industrial sectors. This has, in fact, generated a considerable network of material flows between different wood processing industries that use co-products from other sectors as material input or fuel, e.g. chips from saw mills are used in the particleboard industry (KORHONEN et al. 2001).

Even after the use phase of wooden products, the material characteristics of wood (theoretically) still allow for a variety of options for the reuse of wood as material or an energy source. These options are further discussed in chapter 3.

Similar considerations on the generation and use of co. products within the material chain are also valid for the pulp and paper chain. In contrast to the wood processing industry, the (material) recycling of waste paper is a widely established state-of-the-art industry.

\section{Utilisation options of post-consumer wood}

Due to the material characteristics of wood and its twofold nature as material and energy carrier, a variety of options are open for the reuse and recycling of post-consumer wood. They are mainly restricted by the size of the post-consumer wood, particles or fibres, their homogeneity, and their content of contaminants (e.g., from preservatives, coatings, adhesives, foils, overlays, etc.).

The guideline VDI-2243 by Verein Deutscher Ingenieure (table 3) identifies four distinct options of reuse and recycling of materials and products, depending on the area of application and the technical effort required in reprocessing.

The first two options are considered "closed-loop" recycling according to ISO/EN 14041, while the second two are classified as "open-loop" recycling. However, to a certain extent, the classification of a specific case to one of the four options is subjective. Should the production of particleboard from a massive wood board from furniture be classified as reuse or recycling? Should a laminated wood beam made from a massive wood beam be classified as recycling?

The classification becomes even trickier when thermal utilisation has to be classified. When should the incineration of post-consumer wood be considered under the aspect of waste disposal or when should it be classified as thermal recycling?

\section{Post-consumer wood market in Switzerland}

A variety of definitions for post-consumer wood ("Altholz") can be found in Swiss legislation and governmental strategy papers. This variety is a consequence of difficulties encountered while defining this material category and the result of particular interests related to post-consumer wood (SCHELleR 2001).

For this study, the term "post-consumer wood" is used according to the following definition: "Wood-based materials such as massive wood, plywood, particleboard, fibreboards, MDF etc., that leave the use process at the consumer after a shorter or longer service life, are considered post-consumer wood. The wooden parts can have been subject to various treatment processes during production; during service life, they might have been combined with different materials. Usu- 
Table 3: Reuse and recycling options at the end of the life cycle of wood products (after RICHTER 2000; WILLEITNER \& BUCKI 1994).

Tabelle 3: Verwendungs- und Verwertungsoptionen von Holzprodukten am Ende ihres Lebenszyklus (nach RICHTER 2000; WILLEITNER \& BUCXI 1994).

Reuse in same application ("Wiederverwendung")
Technical effort

for reprocessing small

Inherent material properties unchanged (repair, renovation)
Area of application product $1 \rightarrow$ product 2 same

Example

returnable pallets, spare part exchanges second hand furniture dealers

Recycling in different

applications

reprocessing

slightly changed

same

("Wiederverwertung")

necessary

massive wood beam

$\rightarrow$ laminated wood beam

particleboard

$\rightarrow$ particleboard

Reuse in different applications

("Weiterverwendung")

smail

unchanged

different

Recycling in different

applications

("Weiterverwertung")

reprocessing

necessary

changed

mostly different

railway sleepers, utility

poles in landscape architecture

post-consumer wood

$\rightarrow$ particleboard

$\rightarrow$ MDF

$\rightarrow$ thermal energy

ally, the treatment and use processes, which post-consumer wood was subject to, are only rudimentarily known" (Vock et al. 1993: 8; translated from German by WF).

While data on wood consumption is readily available (WIEGAND et al. 1996; ANONYMOUS 2000a), data on the postconsumer wood market in switzerland must be considered sketchy (SCHELLER 2001; VocK 2000). Estimations on the postconsumer wood sources and its sinks are shown in table 4.

In the meantime, two relevant changes in legislation have taken place:

- based on the Technical Ordinance on Waste, landfilling of combustible waste fractions has been forbidden since the 1st of January 2000 (TVA, Art. 53a);

- exports of post-consumer wood have to be declared (ANONYMOUS 1998b).

Material use of post-consumer wood on an industrial scale has been insignificant in Switzerland. In Germany the average contents of post-consumer wood lies between $5-20 \%$ while in Italy, for example, wood-based boards are produced from $100 \%$ post-consumer wood (HARBEKE 1998; SCHRäGLE 2001). swiss particleboard producers have so far abstained from using post-consumer wood in their products, most probably for reasons of image of their products. Instead, Swiss post-consumer wood is exported mainly to Italy. These exports will probably increase because it is a considerably cheaper option than the disposal of post-consumer wood in municipal waste incinerators or post-consumer wood incinerators in Switzerland (HOFER 2000).

Political programs, such as «Energie 2000 » and its follow up "EnergieSchweiz", have been set up to foster the use of wood as an energy carrier.
Despite governmental support, the use of wood as an energy carrier has been stable in recent years (ANONYMous 2000a). Nevertheless, the use of post-consumer wood as a source of energy in Switzerland is losing importance; large post-consumer wood incineration facilities, like the concrete plant in Rekingen, have been closed down for economic rea. sons. Similarly, some owners of post-consumer wood incineration plants consider switching from post-consumer wood to alternative waste fuels (HOFER 2000). On the other hand, capacities of existing municipal waste incineration plants are almost exhausted (ANONYMOus 2001), and it is doubtful whether these plants will be able to absorb the increased amounts of post-consumer wood in the future.

\section{Options for material re-utilisation of post-consumer wood}

\section{Reuse of wooden products}

Direct reuse of wood on an industrial scale is not usually pos. sible. Because of differing shapes, quality and impurities, labour-intensive, expensive reprocessing is required (STAHEL et al. 1987). Nevertheless, the reuse of wooden pallets (HEKKERT et al. 2000) and packaging elements, as well as the reuse of standardised building materials, such as laths, beams or boards on a small scale, decentralised single cases are common practice (Stahel et al. 1987; OrPIN 1996; Plume 1996).

Another exception, also small in quantities, consists in the reuse of valuable timber, antique and handcrafted furniture, panels, wall panels, parquet floorings, as well as, occasionally, old doors and windows. In some cases, salvaged wood

Table 4: Estimated current sinks and sources of post-consumer wood in Switzerland (after Vock 2000; with data from AnOnYmous 1998C; ANONYMOUS 1999d).

Tabelle 4: Geschätzte gegenwärtige Quellen und Senken von Altholz in der Schweiz (nach Vocx 2000; basierend auf Daten von ANONYMOUS 1998c; ANONYMOus 1999d).

\begin{tabular}{lrlr} 
Post-consumer wood sources & tyear & Sinks & tyear \\
Building parts & 300000 & Municipal waste incinerators (estimation) & 220000 \\
Furniture and wooden goods & 235000 & Landfilling (estimation) & 30000 \\
Packaging & 165000 & & Firing systems (BFE-statistics 99) \\
& & Exports (Exports-statistics 99) & 80000 \\
& & lllegal disposal (estimation) & 160000 \\
& & Total & 210000 \\
\hline Total & 700000 & & 700000 \\
\hline
\end{tabular}




\section{Recycling in wood-based panels}

Wood-based panels, such as particleboards or fibreboards (e.g. medium density fibreboards, MDF) are sold in large quantities and have low unit prices.

Various processes have been developed for the reintegration of particles and fibres from used boards (WITTKE 1998; Möller \& Herrlich 1994; Dupré 1986:143; Roeffael 1997; MICHANICKL \& BOEHME 1995).

Panel board manufacturers have defined quality specifications for post-consumer wood fractions suitable for woodbased panel production (ANONYMOUS 1996b; ANONYMOUS 1999b; Krooss et al. 1998; SCHRÄGLE 2001). Further on, quality management systems ensure that the quality of their products complies with the quality requirements whether they contain recycled material or not (HARBEXE 1998).

Even the possibility of using chromated copper arsenate (CCA-) treated wood in the production of particleboard and flakeboard has been investigated, mainly in the U.S. (FELTON 1996; SMith \& Shiau 1998; Mengeloglu \& Gardner 2000). However, at present there are no known commercial markets for recycled CCA-treated wood products, mainly due to environmental concerns related to residual chemicals left in the fibres and due to health and safety concerns of the mill workers (SMITH \& SHIAU 1998).

Quantitatively, the use of post-consumer wood in the wood-based board industry is the most important (and most promising) path for the material utilisation of post-consumer wood (MARUTZKY 1997).

\section{Recycling in wood fibre reinforced plastic composites («plastic lumber»)}

The integration of post-consumer wood fibres into synthetic material is one of two options of wood-based composite materials (see also below). Wood fibre reinforced composites allow the recycling of plastics and of post-consumer wood.
Wood fibre reinforced composites are currently used in automotive industry and for submarine building structures.

Possible content and leakage of harmful substances are a major concern related to the recycling of these post-consumer materials (Various 1997; Various 1992; Hettinga 1996). The ability to recover the embodied energy of wood is maintained.

\section{Recycling in concrete-bond wood fibreboards}

Wood (and waste paper) can also be combined with concrete to produce composite products. The wood aggregate is mixed with Portland cement to form lightweight, fireproof building materials, components and insulation material. The organic fibre makes up 91 percent (by volume) of the total composition (ANONYMOUS 1996c). For these products, the recovery of the embodied energy of wood is inhibited.

\section{Recycling in pressed wood fibre pallets}

Pallets can be pressed from low-grade wood fibres, mostly bark and residues from thinning, but also from post-consumer wood. The fibres are moulded into a pressed wood pallet with the use of synthetic organic resins (HEKKERT et al. 2000).

Recycling as soil amendment, animal bedding or mulching material as peat substitute

The production of soil amendment, animal bedding or mulching material as a peat substitute offers a universal utilisation option for wood residues from wood processing or post-consumer wood. The requirements on technical properties are low for this option, although high standards that ensure the lack of harmful chemicals have to be complied with. This is not, however, a very lucrative option (WILLEITNER \& BUCKI 1994; ANONYMOUS 1999a).

\section{Recycling as chemical basis materials}

The extraction of the main chemical parts of wood, the cracking of the wood substance into monomer fractions, as well as the extraction and use of accessory components (e.g. methanol) is theoretically feasible. For cost reasons, the production of chemical basis material is currently only done on a very small scale. The use of wood as a provider of chemical raw materials is limited to some marginal areas of industrial production and has very limited practical importance (WILleItNeR \& BUCKI 1994; ANONYMOUS 1995; KUSIAN 2001).

\section{Thermal utilisation}

Thermal uses of post-consumer wood range from industrial scale combustion to decentralised combustion in open fireplaces of private houses. Among these options are:

- combustion in municipal waste incinerators with energy recovery;

- residual wood and post-consumer wood combustion plants, mostly associated with the wood-processing industry, but also independent ones;

- combustion in cement kilns which, due to high combustion temperature and due to the specific characteristics of clinker, allows the environmentally sound combustion of preservative-treated post-consumer wood (like creosote treated railway sleepers) (STAHEL et al. 1987; ANONYMous 1998a);

- incineration in open fireplaces of private houses, which is related to high quantities of highly harmful emissions (Vock 2000; NUSSBAUMer 1994). 
The thermal use of wood allows the generation of thermal energy (e.g. as vapour) and/or electricity (Nussbaumer et al. 1997).

End-of-life options from which no further utility is derived are, e.g., the incineration in municipal waste incinerators or as hazardous waste without energy recovery, open burning, landfilling, and dumping.

\section{Economics of post-consumer wood}

Following economic preconditions for the material utilisation of post-consumer wood must be taken into account:

- wood and wood products to be recycled have to be available in sufficient quantities; this concerns mainly questions of logistics, transport, storing, and processing;

- wood and wood products to be recycled have to be steadily available on a mid- to long-term basis, in order to attract investment;

- wood and wood products to be recycled have to be available at prices that make the use of these materials economically viable;

- there must be an acceptance and demand for products partiy or entirely produced from post-consumer wood;

- the reuse and recycling of post-consumer wood must pose no foreseeable disposal problems in the future (WILLEITNER \& BueKI 1994).

Cost and price of post-consumer wood is determined by the following factors (after HAR8EKE 1998):

- state of reprocessing:

- quality, especially the contents of potential harmful substances;

- quantities to be delivered;

- further demand from derived timber product industry and thermal energy producers;

- purchaser's and supplier's strategic goals;

- quotas for the processing of post-consumer wood;

- regional post-consumer wood supply.
The possible content of harmful organic or inorganic chemicals from wood preservatives, glues, coatings, etc. is a major restriction and of great concern in the reuse and recycling of post-consumer wood (see below).

Figure 1 gives an overview of the relative value of wood residues and post-consumer wood fractions and the relative revalorisation potential of the different end-of-life options discussed above.

\section{Wood flow management politics in the light of sustainable development}

The sustainable management of post-consumer wood can only be discussed taking the whole wood chain into account, starting at forestry.

\section{Forestry}

In Europe, the local potential of wood as a resource is currently not exploited to its full extent (ANONYmous 1999C). Also in Switzerland, the average standing volume of wood per hectare must be described as high, and is increasing. Furthermore, forested area in Switzerland has been increasing constantly over the last fifty years. As a consequence of current under-exploitation, Swiss forests contain a disproportionally high share of elderly trees (BRASSEL \& BRÄNDLI 1999).

Even after defining large forest areas as protected nature reserves, the harvesting of wood could be increased by an average of $20 \%$ to $40 \%$. (MAUCH et al. 1995; ANONYMOUs 2000b). Mainly imports of raw material for paper industry could be substituted (MAUCH et al. 1995; Hofer et al. 2001).

Quantitative criteria for sustainable forest management related to forested area and wood quantities harvested are generally met in Switzerland and the legal framework is considered appropriate. Nevertheless, other criteria, e.g., the over-aged mountainous forests, the forest ecosystem health and vitality affected by air pollution and a high degree of gov-

\section{Recovered Wood Types}

Clean Wood
Green Wood \& Mill Residuals
Mill Residuals
Forestry Residuals
Agricultural Wood
Land Clearing Wood
Brush \& Branches
Manufactured \& Construction Wood
Pallets \& Crates
Lumber
Engineered Wood
Sorted Demolition Wood
MIXED WOOD WASTE
Demolition Wood Waste
Roofing \& Siding

Commingled Demolition Wood Waste Treated Wood Waste

\section{End Use Opportunities}

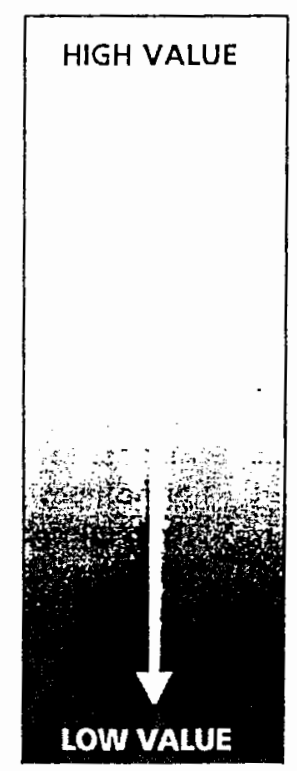

Re-sale or Re-use

High Value Fiber Markets

Pulp \& Paper Applications

Reconstituted Wood Products

Composite Products

Mid-Value Applications

Cellulose \& Molded Pulp

Mulch Products \& Soil Amendment

Animal Bedding

Interim Road Bed

Compost Bulking

\section{Biofuels Combustion}

Chemical Derivatives/Gasification

Processed Fuels: Pellets/Bends Hog Fuel

Disposal

Figure 1: Residual wood and post-consumer wood fractions, possibilities of end-use and their corresponding relative market value (after HORNE-BRINE 1996).

Abbildung 1: Holzabfälle und Altholz, ihre Verwendungs- und Verwertungsmöglichkeiten und ihr entsprechender relativer Marktwert (nach HORNE-Brine 1996). 
ernmental subsidies of forestry activities are major concerns in the light of sustainable forest management in Switzerland. On the other hand, native species cover more than $99 \%$ of the forest area (PATOSAARI 2000; BrasSEL \& BRÃNDLI 1999).

Scant attention has been paid to another aspect: the closing of the cycle of nutrients that are withdrawn from forests, mainly with bark and branches. First experiences have been gained in the use of wood ashes as fertiliser. In this respect, the forest industry activity is beginning to participate in the recycling of nutrients, as base cations in the ashes are returned to the forests. In future, this effort should be increased to complete the natural-industrial nutrient cycle (KORHONEN et al. 2001; WINKLER 1996).

An increased use of local wood in Switzerland would not only respect the environmental dimension of sustainable development but would also foster its social and economic dimensions by providing income in marginalised regions.

\section{Use of wood}

Based on the concept of sustainability, a reduced use of virgin natural resources and a relative shift from non-renewable to renewable resources has to be fostered. An expanded use of renewable materials following from the replacement of nonrenewable resources, however, leads, ceteris paribus, to unacceptable pressure on land resources (MüLleR 1996). The efficiency of resource utilisation needs to be increased in order to reduce or - even better - avoid this pressure (FrAANJE 1997; SCHULz 1972).

However, the claim for dematerialisation - the fulfilment of a need using less material and energy input - does not make an exception for wood. But - contrary to all other important materials, such as steel, aluminium or concrete the resource efficiency of wood need only be increased by a factor of 2 - instead of a factor of 3 to 8 - in order to reach sustainable consumption levels in Europe (MaUCH et al. 1995). Basically, this requires a more effective and efficient use of wood, including optimised process technology and products with longer service lives and an aptitude for repair, material recycling, and, finally, incineration with energy recovery (Werner 1999; Lafleur \& FraAnje 1997).

FraANJe (1997) states that wood is often not used according to the "appropriate application»-principle of resource cascading (see SIRKIN \& TEN HOUTEN 1994). "Appropriate application means that the resource is applied on the basis of its (typical) properties, at the highest possible quality level. Following this principle, pulp should not be made directly out of trees, but first profit from specific qualities of massive wood (like strength). When making paper directly from vegetable resources, one should rather use flax or hemp, instead of wood. Appropriate application has reference to the whole resource" (FraANJe 1997: 24).

Use of primary wood in energy production is not economically feasible under current market conditions in Switzerland, owing to the high costs of labour and the infrastructure of fuel preparation (HOFER 2000). Hence, only the use of wood as material generates enough revenue to cover current forest exploitation costs.

\section{Post-consumer wood}

Handling post-consumer wood is situated between waste treatment/disposal and exploitation of a secondary material resource for material or energy purposes (ANONYMOUs 1995; ANONYMOUS 1996a; Voss 1998).

The reuse and recycling of post-consumer wood brings both advantages and disadvantages. Among the advantages are (MarutzKy 1997; Roeffael 1997):
- reintegration of waste into the economy;

- careful treatment of resources and amplification of the resource basis;

- less occupation of space in landfills;

- substitution of fossil fuels $\left(\mathrm{CO}_{2}\right.$-neutrality of wood);

- lower thermal energy consumption and VOC-emissions from drying processes if used (dry) wood is recycled as material;

- higher energy efficiency due to lower moisture content compared to "fresh" wood if used for energy purposes;

- destruction of harmful (organic) chemicals or their immobilisation and export from ecosphere (in the case of inorganic chemicals) when used for energy purposes in cement kilns.

Among the disadvantages are:

- dispersion of pollutants if recycled as material (see below);

- generation of harmful emissions when used for energy purposes in unsuited incineration plants;

- higher requirements on logistics and transports than primary material;

- displacement of other wooden raw materials such as residues from thinning or sawmills leading to lower prices for products from primary processes with already low profits, or even from subsidised sources;

- even less economically viable wood extraction and a correspondingly reduced potential substitution of fossil fuels.

Environmentally relevant problems specifically related to the incineration of post-consumer wood are (after NussBAUMER 1994):

- high ash content and low ash melting temperature;

- fuel nitrogen leading to $\mathrm{NO}_{x}$ emissions;

- sub-optimal combustion processes as a consequence of wood as solid fuel leading to the emission of $\mathrm{NO}_{x^{\prime}} \mathrm{CO}$ and particles;

- chlorine in the fuel leading to $\mathrm{HCl}$ emissions or even to PCDD/F :

- heavy metals ( $\mathrm{Pb}, \mathrm{Zn}$ ) causing respective emissions;

- stones, sand, metals, etc. as contaminants.

For both material and energy usage of post-consumer wood, the potential content of harmful substances from chemical wood conservation is a major limitation. The agents applied (biocides) are designed for a long persistence. They remain in the wood even after the service life of the product is reached and can thus considerably limit the use and disposal options of the post-consumer wood. Among the substances used for their biocidal character are mercury, zinc, chrome, copper and arsenic compounds, creosote or pentachlorophenol ( $P C P$ ).

Processes have been developed for removing organic wood preservatives (creosote) from post-consumer wood in order to allow its use as secondary material in the particleboard industry. However, such processes have not been put into industrial practice (KüHNE \& SCHWARZ 1997).

Other sources of substances that limit the further utilisation of post-consumer wood, apart from chemical wood preservatives, are glues, toxic pigments of coatings or colours and mineral contaminants.

Combustion of post-consumer wood is mainly limited because of the content of heavy metals and chlorine from chloro-organic compounds (e.g. lindane).

Up to now, no labelling scheme has been put into practice (although it is currently being discussed). Visual distinction of untreated and treated post-consumer wood, in the latter case differentiating between organic and inorganic active groups, is feasible only to a very limited extent. In practice, it is limited to certain homogenous fractions such as utility poles or rail- 
way sleepers (PEEK 1998). Large-scale analytic techniques for the sorting of post-consumer wood according to its contamination are currently being investigated in pilot plants (PEYLO 1998a; PEYLO 1998b; WeIs et al. 1999).

Limits to the recycling of post-consumer wood are not only set by the possible content of harmful substances but also by the unavoidable degradation of material during reprocessing. Degradation during reprocessing includes, e.g., a reduction in dimension of wooden parts, an unavoidable amount of sawdust produced during reprocessing, more cubical dimensions of reprocessed secondary chips for particleboard production (if applying dry separation processes), or reduced fibre length of reprocessed fibreboard or paper, etc.

The above situation requires three basic strategies in order to extend the utilisation potential of post-consumer wood as a secondary resource:

- labelling of wood products with declaration of used additives;

- utilisation of homogenous materials concerning the type of wood used and the use of wood-based intermediate products, and with regard to the treatment with substances limiting further utilisation;

- simple structure of wood products to facilitate disassembly and the recuperation of homogenous fractions free of substances limiting further (thermal) utilisation.

\section{Management rules for a sustainable utilisation of post-consumer wood}

Since the beginning of the debate on environmental issues in the 80 s, the utilisation of post-consumer wood has been subject to increasing control and regulatory work. A number of directives (TVA, StoV, LRV) based on the Federal Law on Environmental Protection (USG) and some international conventions ("Basle Convention" and the OECD-resolution C(92)39/ FINAL) regulate the utilisation of post-consumer wood and correspond to its threefold nature as waste, secondary material or fuel.

According to the Waste Concept of Switzerland (ANONYmous 1992) the following four strategies have to be followed for the post-consumer use of wood, in descending order of importance:

1. reducing waste at the source;

2. minimising pollutants in processes and products;

3. reducing waste by improved recovery operations;

4. improving domestic treatment facilities for non-recoverable wastes.

In principle, material re-utilisation of waste has priority over thermal utilisation. Given the current conditions, this does not hold for post-consumer wood for two reasons:

1. post-consumer wood fractions can be contaminated with heavy metals or organic substances. Instead of concentrating and disposing of these contaminants, they are more likely to be distributed and reintegrated into anthroposphere. This leaves unsolved the problematic nature of contaminated post-consumer wood and may even accentuate problems in the future. The dilution of contaminated waste is forbidden under the Technical Ordinance on Waste (TVA, Art. 10);

2. for economical reasons, the potential of European forests as fuel suppliers is not exploited; currently only the revenue arising from material uses justifies the cost of harvesting the wood. Forests remain largely unexploited when wood is recycled and the substitution potential of wood for fossil fuels is not fully utilised.
HOFER (2000) therefore proposes four basic strategies for the management of post-consumer wood:

1. post-consumer wood generated in Switzerland will be supplied to thermal utilisation if feasible under sustainable conditions;

2. material utilisation within Switzerland and abroad will fulfil environmental requirements equivalent to the thermal utilisation of post-consumer wood in Switzerland;

3. disposal/treatment of post-consumer wood will comply with legal regulations;

4. the quality of post-consumer wood will be improved on a mid- to long-term basis (HOFER 2000: 19; translated from German by WF).

\section{Conclusions}

This article enters in to the current environmental discussion of post-consumer wood, taking the entire wood chain into account. We have discussed the current situation and potential use options of wood - particularly post-consumer wood in Switzerland - and outlined the wood flow politics in the light of sustainable development. Summarising the above chapters, we have identified following principles for a sustainable use of wood in general and post-consumer wood in particular:

1. wood production in forestry respecting qualitative and quantitative criteria for sustainable forest management;

2. efficient and effective processing and use of wood as material in wood industry;

3. renunciation of chemical wood protection where possible (e.g. by constructive means) and careful selection of additives like foils, glues, coatings etc. (see also dot 5);

4. products that can easily be disassembled thus providing single-material fractions for easy recycling and incineration in appropriately equipped plants;

5. maintenance of the incineration potential for the substitution of non-regenerative fossil fuels;

6. recovery of the used-wood-based ash from power plants and returning it to the forest ecosystem to serve as fertiliser in an ecologically acceptable way;

7. incineration of post-consumer wood and maximisation of the substitution of fossil fuels;

8. maximisation of the amount of wood stored in long-term applications such as buildings.

These principles need to be addressed and given serious consideration during the modelling of wood and wood-based products in environmental decision-support tools.

\section{Summary}

Model-based environmental decision-support tools, such as life cycle assessment or material-flow analysis, only lead to rational decisions when material and market characteristics of a material or product are addressed and adequately depicted during modelling. Post-consumer wood provides a special challenge to modellers due to the variety of reuse, recycling and disposal options, the legislative framework and the usual role of wood in the discussion of sustainable development.

This article provides a description of the current environmental discussion of wood "from cradle to grave», on which methodological decisions can be based during the modelling in decision-support tools. The current situation and potential use options of wood - particularly post-consumer wood in switzerland - are outlined, and the wood flow politics dis- 
cussed in the light of sustainable development. Finally, this paper contains an extensive review of recent literature on wood in the environmental discussion with emphasis on sus. tainable use options of post-consumer wood in Switzerland.

\section{Zusammenfassung}

\section{Altholz in umweltbezogenen Entscheidungs- instrumenten}

Umweltpolitische, auf Modellierung beruhende Instrumente zur Entscheidungsunterstützung wie Lebenszyklusanalysen (Ökobilanzen, LCA) oder Stoffstrommodelle führen nur zu rationalen Entscheidungen, wenn es bei der Modellierung gelingt, die material- und marktspezifischen Eigenheiten eines Stoffes oder Produktes abzubilden. Altholz stellt durch die Vielzahl von Entsorgungswegen, gesetzlichen Rahmenbedingungen und generell der Rolle von Holz in der Nachhaltigkeitsdiskussion für die Modellierung eine besondere Herausforderung dar.

Der Artikel umfasst eine Beschreibung der gegenwärtigen Umweltdiskussion "von der Wiege bis zur Bahre», auf die methodische Entscheidungen bei der Modellierung von Altholzströmen abgestützt werden können. Weiter werden die gegenwärtigen und potenziellen Verwertungs- und Entsorgungswege von Altholz fokussiert auf die Schweiz umrissen und Management-Regein für nachhaltige Bewirtschaftung der Altholzströme hergeleitet. Ausserdem enthält der Artikel eine umfangreiche Literaturübersicht zum Thema Althoiz und Nachhaltigkeit in der Schweiz.

\section{Résumé}

\section{La gestion du bois usagé, instrument d'aide} à la décision sur le plan environnemental

Les instruments d'aide à la décision en matière de politique environnementale qui sont basés sur la modélisation - comme les analyses du cycle de vie (écobilans) ou les modèles de flux de matière - ne permettent des décisions rationnelles que lorsque la modélisation parvient à reproduire fidèlement les particularités matérielles et économiques d'une matière ou d'un produit. Le bois usagé constitue un défi particulier pour la modélisation en raison de la multiplicité des possibilités d'élimination, des dispositions cadres de la loi et, plus généralement, en raison du rôle de ce matériau dans la discussion sur la gestion durable.

Le présent article fournit une description du débat actuel sur l'environnement pouvant servir d'élément de base à la méthodologie de modélisation des flux de bois usagé. II décrit ensuite les possibilités actuelles et potentielles de valorisation et d'élimination du bois usagé en Suisse, puis discute les règles de la gestion durable des flux de bois usagé. De plus, l'article contient une vaste bibliographie sur le thème du bois usagé et de la gestion durable en Suisse.

Traduction: CLAUDE GASSMANN

\section{References}

Anonymous (1992): Abfallkonzept für die Schweiz; Ziele, Massnahmen. Wirkung. Schriftenreihe Umwelt SRU 173, Bundesamt für Umwelt, Wald und Landschaft (Buwal), Bern.

AnONYMous (1995): DGfH-Merkblatt: Stoffliche Verwertung von Holz und Holzwerkstoffen. Deutsche Gesellschaft für Holzforschung e.V. (DGfH), München.
ANONYMOUS (1996a): DGfH-Merkblatt: Energetische Verwertung von Altholz. Deutsche Gesellschaft für Holzforschung (DGfH), München.

ANonYmous (1996b): Gebrauchtholzverwertung in der Holzwerkstoffindustrie; Qualitätsbestimmungen für die Annahme zur stofflichen Verwertung. Holz-Zentralblatt 122 (75): 1213-1214.

Anonymous (1996c): Supply of Recovered Wood and Paper is an Impetus for Recycling. Industrial Uses 6 (96/9): 30-31.

ANONYMOUS (1998a): Entsorgung von Abfăllen in Zementwerken; Richtlinie. Bundesamt für Umwelt, Wald und Landschaft (Buwal), Bern, http://www.buwal.ch/abfall/docu/pdf/d_zementwerkrichtlinie.pdf.

ANONYMOUS (1998b): Export und Import von Altholz; Empfehlungen und Hinweise für den Exporteur und die Zollorgane, Stand 16.08.98. Bundesamt für Umwelt, Wald und Landschaft (Buwal), Bern.

ANONYMOUS (1998c): Schweizerische Vereinigung für Holzenergie; Schwerpunkt Altholz. Schweizerische Vereinigung für $\mathrm{Holz}$. energie, Maschwanden.

ANONYMOUS (1999a): Gewinnung von Substraten für Gartenbau und Landwirtschaft aus Spanplatten- und MDF-Resten. WKI-Kurzbericht Nr. 20, Braunschweig.

ANONYMOUS (1999b): Qualitätsanforderungen an den Rohstoff Holz Wald, Rest- und Gebrauchtholz für den stofflichen Einsatz in Holzwerkstoffen. Holz-Zentralblatt 125(7): 70-71.

ANONYMOUS (1999c): State of European Forests and Forestry. Timber Section, UN/ECE Trade Division, Geneva, http://www.unece.org/trade/timber/docs/sp/eur-for/sp16.htm\# Overview.

ANONYMOUS (1999d): Statistik der erneuerbaren Energieträger Bundesamt für Energiewirtschaft (BEW), Bern.

ANONYMOUS (2000a): Wald und Holz in der Schweiz; Jahrbuch 2000. Statistik der Schweiz, Bundesamt für Umwelt, Wald und Landschaft (Buwal), Bundesamt für Statistik (BFS), Neuenburg.

ANONYMOUS (2000b): Waldpolitik Bund; 5chwerpunkte des Eidg. Departementes für Umwelt, Verkehr, Energie und Kommunikation. Dokument 3 zur Vernehmlassung, Eidgenössische Forstdirektion, Bern.

ANonymous (2001): Die Abfallberge türmen sich unvermindert; Keine Entkoppelung von Wirtschaftsentwicklung und Abfallaufkommen. Neue Zürcher Zeitung 265(100): 15.

BACCINI, P. and BRUNNER, P.H. (1991): Metabolism of the Anthroposphere. Springer Vert., Berlin, New York.

BowYER, J. (1995): Wood and Other Raw Materials for the $21^{\text {st }}$ Century. Forest Products Journal 45(2): 17-24

BRASSEL, P. and BRẢNOLI, U.-B. (1999): Schweizerisches Landesforstinventar. Ergebnisse der Zeitaufnahme 1993-1995. Haupt-Verl., Bern u.a.

BUSER, B. (1998): Die Bauteilbörse. Schweizerischer Ingenieur und Architekt 13: $203 \mathrm{ff}$.

CLĖNin, P. (2001): Nachhaltigkeit bis am Schluss...; Das Holz des Schweizer Expo-2000-Pavillons wurde in fünf Länder verkauft. Schweizer Holzzeitung 113(15): 6.

DUPRE, F. (1986): Aufbereitung von Holzabfällen aus Baurestmassen als Brennstoff für Kleinfeuerungen. In: Thomé-Kozmiensky, K.J. (ed.): Recycling von Holz, Zellstoff und Papier; Beiträge des 5. Internationalen Recycling Congresses. EF-Verl. für Energie- und Umwelttechnik, Berlin: 143-147.

ELDAG, H. (1980): Wood and Wood Products. In: Altenpohl, D.G. (ed.): Materials In World Perspective; Assessment of Resources, Technologies and Trends for Key Materials Industries. SpringerVerlag, Berlin u.a.: 105-117.

FELton, C.C. (1996): The Recycling Potential of Preservative-Treated Wood. Forest Products Journal 46(7/8): 37-46.

Fraande, P.J. (1997): Cascading of Pine Wood. Resources, Conservation and Recycling 19(1): 21-28.

FrühWald, A., Wegener, G., SCharal-Rad, M. Zimmer, B. and Hascm, J. (1996): Grundlagen für Ökoprofile und Ökobilanzen in der Forst- und Holzwirtschaft. Ordinariat für Holztechnologie der Universität Hamburg, Institut für Holzforschung der Universitāt München, in Zusammenarbeit mit Bundesforschungsanstalt für Forst- und Holzwirtschaft, Hamburg.

FrüHWALD, A., SCharal-RAD, M. and Hasch, J. (2000): Ökologische Bewertung von Holzwerkstoffen; Schlussbericht, ergänzt in den Bereichen Spanplattenrecycling und OSB-Bilanzen. Ordinariat für Holztechnologie der Universität Hamburg, Hamburg. 
Frühwald, A., Pohlmann, C.M. and Wegener, G. (2001): Holz, Rohstoff der Zukunft; nachhaltig verfügbar und umweltgerecht. Deutsche Gesellschaft für Holzforschung (DGfH), München.

Guinnée, J.8., Gorrée, M., Heijungs, R, et al. (2001): Life Cycle Assess ment; An Operational Guide to the ISO Standards; Final Report, May 2001. Ministry of Housing, Spatial Planning and Environment (VROM) and Centrum voor Milieukunde (CML), Rijksuniversiteit, Leiden, http://www.leidenuniv. $\mathrm{nl} / \mathrm{cml} / \mathrm{lca} /$ index.html.

Harbexe, T. (1998): Gebrauchtholz in der Holzwerkstoffindustrie. In: Umweltschutz in der Holzwerkstoffindustrie; Tagungsband der Fachtagung am 24. und 25. Juni in Göttingen. Institut für Holzbiologie und Holztechnologie, Göttingen: 66-83.

HEKKERT, M.P., JOOSTEN, L.A.J. and WORRELL, E. (2000): Reduction of $\mathrm{CO}_{2}$ Emissions by Improved Management of Material and Product Use; The Case of Transport Packaging. Resources, Conservation and Recycling 30(1): 1-27.

Hettinga, S. (1996): Recycled Wood: the ideal Filler for Plastic. In: Falk, R.H. (ed.): The Use of Recycled Wood and Paper in Building Applications. The Forests Products Society, Madison/Wis.: $82-83$.

Hofer, P. (2000): Ansätze zu einer schweizerischen Altholzpolitik; vom Überfluss zum Mangel und zurück. SAH bulletin CSRB: Altholz zwischen Verwertung und Beseitigung 5: 16-23.

HOFER, P., MORF, L., TAVERna, R. and Richter, K. (2001): Speicherung von $\mathrm{CO}_{2}$ in Holzlagern im Zivilisationskreislauf um Emissionseffekte der Substitution bei gesteigerter Hoizverwendung. GEO Partner, Zürich.

Hofstetter, T., Baumgartner, T. and SCholz, R.W. (2000): Modelling the Valuesphere and the Ecosphere: Integrating the Decision Maker's Perspectives into LCA. International Journal for Life Cycle Assessment 5(3): 161-175.

HORNE-8RINE, P. (1996): The Explosive Growth of Wood Recycling in the Pacific Northwest. In: Falk, R.H. (ed.): The Use of Recycled Wood and Paper in Building Applications. The Forests Products Society, MadisonMis.: 34-40.

Jungmeler, G., Werner, F., Jarnehammer, A., Hohenthal, C. and RICHTER, K. (2002): Allocation in LCA of Forestry Products Recommendations from COST E9. In: Jungmeier, G. (ed.): International Journal for Life Cycle Assessment, in review.

KORHONEN, J., WIHERSAARI, M. and SAVOLAINEN, 1. (2001): Industrial Ecosystems in the Finnish Forest Industry: Using the Material and Energy Flow Model of a Forest Ecosystem in a Forest Industry System. Ecological Economics 39: 145-161.

Krooss, J., Stolz, P., Thurmann, U., Wosniok, W., Peek, R.-D. and GIESE, H. (1998): Statistisch ermittelte Hintergrundkonzentrationen für Schwermetall-und Holzschutzmittel-Wirkstoffgehalte naturbelassener Althölzer. Holz-Zentralblatt 124(46): 689-695.

KüHNE, G. and SCHWARz, U. (1997): Möglichkeiten der Detoxifizierung von steinkohlenteerölimprăgnierten Althölzern und deren stoffliche Nutzung. In: Kharazipour, A. and Roeffael, E. (Hrsg.): Recyclingkonzepte in der Holzwerkstoffindustrie. Institut für Holzbiologie und Holztechnologie, Göttingen: 75-89.

KUsIAN, R. (2001): Schwarze Pumpe produziert Treibstoff aus Altholz. Holz-Zentralblatt 127(31): 455 .

LAFLeUR, M.C.C. and FraANJe, P.J. (1997): Towards Sustainable Use of the Renewable Resource Wood in the Netherlands - a Systematic Approach. Resources, Conservation and Recycling 20(1): 19-29.

MARUTZKY, R. (1997): Entsorgung von Rest- und Gebrauchtholz: Eine Bestandesaufnahme der aktuellen Situation in Deutschland. Holz-Zentralblatt 123(146): 2201/2204.

Mauch, S., von Stoxar, T., Zurcher, D., Heldstab, J., Schreyer, C., SEIler, 8., SCHEIdegGer, A., Zanola, V. and TSCHIRREN, J. (1995): Quantitative Aspekte einer zukunftsfähigen Schweiz; Arbeitsbericht. INFRAS, Zürich.

Mengeloglu, F. and GARDNER, D.J. (2000): Recycled CCA-treated Lumber in Flakeboards: Evaluation of Adhesives and Flakes. Forest Products Journal 50(2): 41-45.

MICHANICKL, A. and BOEHME, C. (1995): Verfahren zur Wiedergewinnung von Spänen und Fasern aus Holzwerkstoffreststūcken, Altmöbeln, Produktionsrückständen, Abfällen und anderen holzwerkstoffhaltigen Materialien. DE-OS $19509152 \mathrm{~A} 1$.

MOLLER, A. and HERRLICH, S. (1994): REHOLZ - ein neuer Werkstoff aus Altholz. In: Westkemper, E. (Hrsg.): Marktorientiert, Schlank und Umweltgerecht; Recycling und ökologische Aspekte; 9. Holztechnisches Kolloquium. Vulkan-Verl., Braunschweig. 6.1-6.12.
MúlLeR, D. (1996): Szenarien zur nachhaltigen regionalen Holzbewirtschaftung. Schweiz. Z. Forstwes. 147(11): 873-885.

MúlLER, D. (1998): Modellierung, Simulation und Bewertung des regionalen Holzhaushaltes. Diss., Eidg. Technische Hochschule (ETH), Zürich.

Nuss8aumer, T. (1994): Anforderungen bei der thermischen Verwertung von Holzreststoffen und -abfällen. In: Westkemper, $E$. (Hrsg.): Marktorientiert, Schlank und Umweltgerecht; Recyding und ökologische Aspekte; 9. Holztechnisches Kolloquium. Vulkan-Verl., Braunschweig, 9.1-9.20.

Nussbaumer, T., Neuenschwander, F., Hasler, P., Jenni, A. und Bühler, R. (1997): Energie aus Holz; Vergleich der Verfahren zur Produktion von Wärme, Strom und Treibstoff aus Holz, Im Auftrag des Bundesamtes für Energiewirtschaft (BEW), ENET, Bern.

ORPIN, J. (1996): The Use of Salvaged and Resawn Wood in Fine Homebuilding. In: Falk, R.H. (ed.): The Use of Recycled Wood and Paper in Building Applications. The Forests Products Society, MadisonMis.: 101-103.

PatosaAri, P. (2000): The Swiss Case. Main Results of the Sustainability Assessment of Swiss Forest Policy and its Merits in an Interna. tional Context. Schweiz. Z. Forstwes. 151(12): 480-483.

PEEx, R.-D. (1998): Schadstoffe in Holzabfällen und ihre Bedeutung beim Recycling. In: Umweltschutz in der Holzwerkstoffindustrie; Tagungsband der Fachtagung am 24. und 25. Juni in Göttingen. Institut für Holzbiologie und Holztechnologie, Göttingen: 107-119.

PEyıo, A. (1998a): Schnellerkennung von Holzkontaminationen (1). Holz-Zentralblatt 124(46): 690-692.

PEyLo, A. (1998b): Schnellerkennung von Holzkontaminationen - Ein Überblick. 8undesforschungsanstalt für Forst- und Holzwirtschaft (BFH), Hamburg.

PLUME, G.D. (1996): Reclaimed Timber: A Modern Construction Material. In: Falk, R.H. (ed.): The Use of Recycled Wood and Paper in Building Applications. The Forests Products Society, Madison/Wis.: 104-107.

RICHTER, K. (2000): Altholzverwertung als Teil des Produktlebenszyklus. SAH bulletin CSRB: Altholz zwischen Verwertung und Beseitigung, 5: 10-15.

ROEffAEL, E. (1997): Stand der Kenntnisse beim Recycling von Holzwerkstoffen. In: Kharazipour, A. und Roeffael, E. (Hrsg.): Recyclingkonzepte in der Holzwerkstoffindustrie. Institut für $\mathrm{Holz}$ biologie und Holztechnologie, Göttingen: 4-14.

SCHELLER, M. (2001): Altholzmarkt in der Schweiz; Bericht zur Untersuchung. Eidgenössische Materialprüfungs- und Forschungsanstalt (EMPA), Dübendorf, im Druck.

SCHRÄGLE, R. (2001): Produktequalität gesichert; Qualitätskonzept für die Spanplattenproduktion des SIA Werks in Italien. Schweizerische Holzzeitung 26: 14.

Schulz, H. (1972): Holz im Kreislauf der Wirtschaftsgüter. HolzZentralblatt 98(101): 1415-1417.

Schulz, H. (1993): Entwicklung der Holzverwendung im 19., 20. und 21. Jahrhundert. Holz als Roh-und Werkstoff 51: 78-82.

SIRKIN, T. and TEN HOUTEN, M. (1994): The Cascade Chain; A Theory and Tool for Achieving Resource Sustainability with Applications for Product Design. Resources, Conservation and Recycling 10: 213-277.

SMITH, R.L. and SHIAU, R.-J. (1998): An Industry Evaluation of the Reuse, Recycling, and Reduction of Spent CCA Wood Products. Forest Products Journal 48(2): 44-48.

StAHEL, R., SChuler, B.A. and Lederger8er, E. (1987): Altholz - eine vernachlässigte Ressource. NFP $12 \mathrm{Holz}$, erneuerbare Rohstoff. und Energiequelle, Verlag Rüegger, Grüsch.

SUTTON, W.R.J. (1993): The World's Need for Wood. The Globalisation of Wood: Supply, Processes, Products, and Markets, Forest Products Society, Madison Wis.

VARIOUS (1992): Materials Interactions Relevant to Recycling of Wood-8ased Materials; Symposium held April 27-29, 1992, San Francisco/CA. Materials Research Society Symposium Proceedings, Vol 266, Materials Research Society, Pittsburgh/PE.

VARiOUS (1997): Fourth International Conference on WoodfiberPlastic Composites. Proceedings of the Fourth International Conference on Woodfiber-Plastic Composites, 1997, Madison Wis.: 1-324.

Vocx, W. (2000): Informationen zum Altholzfluss und Resultate aus neuen Untersuchungen. SAH bulletin CSRB: Altholz zwischen Verwertung und Beseitigung, 5: 4-6. 
Ii Vock, W., Jenns, A. and SteINMANn, P.A. (1993): Energie 2000-DIANE 8; Energie aus Altholz und Altpapier; Übersicht Schweiz: Situationsanalyse der energetischen Nutzung von Altholz und Alt. papier. Bundesamt für Energiewirtschaft (BEW), Bern.

Voss, A. (1998): Aufkommen und Zusammensetzung schutzmittelbehandelter Althölzer und ihre Entsorgung. Mitteilungen der Bundesforschungsanstalt für Forst- und Holzwirtschaft, Nr. 188, Bundesforschungsanstalt für forst- und Holzwirtschaft (BFH), Hamburg.

Weis, N., Thurmann, U. and Wosniok, W. (1999): Praktikable Altholzanalyse im Versuch; Probenahmestrategie zur Erfassung von Belastungen inhomogener Altholzmischsortimente. Holz-Zentralblatt 125(145): 1964.

WERNER, F. (1999): Nachhaltigkeit im Holzbau. Schweizer Bauzeitung, Schweizer Ingenieur und Architekt 117(4): 30-32.

WERNER, F., KÜNNIGER, T. and RICHTER, K. (1999): Holzprodukte in vergleichenden Ökobilanzen. Schweiz. Z. Forstwes. 150(3): 96-10.

WERNER, F. (2001): Recycling of Used Wood - inclusion of End-of-life Options in LCA. In: Jungmeier, G. (ed.): Life Cycle Assessment of Forestry and Forest Products; Achievements of COST Action E9 Working Group 3 «End of Life: Recycling, Disposal and Energy Generation". Joanneum, Institute of Energy Research, Graz, $6 / 1-24$.

Werner, F. (2002): Criteria for Mastering Ambiguity in a Subjectivistic Conception of $\mathrm{LCl}$ for Decision-making. International Journal for Life Cycle Assessment, in review.

WIEGANO, U., QueTrING, M. and MEHLISCH, C. (1996): Endverbrauch des Holzes in der Schweiz 1996. Umwelt-Materialien Nr. 94, Bundesamt für Umwelt, Wald und Landschaft (Buwal), Bern.

WILLEITNER, H. und BUCKI, C. (1994): Marktorientiert, Schlank und Umweltgerecht; Recycling und ökologische Aspekte; 9. Holztechnisches Kolloquium. In: Westkemper, E. (Hrsg.): Marktorientiert, Schlank und Umweltgerecht; Recycling und ökologische Aspekte; 9. Holztechnisches Kolloquium. Vulkan-Verlag, Braunschweig, 5.1-5.10.

WINKLER, H.D. (1996): Problematik der Altholzentsorgung. byseSymposium "Altholzrecycling" - ein Markt mit Perspektiven, Umweltamt Nordrhein-Westfalen, Düsseldorf.

WITTKE, B. (1998): Recycling von Holzwerkstoffen im industriellen Massstab. In: Umweltschutz in der Holzwerkstoffindustrie; Tagungsband der Fachtagung am 24. und 25. Juni in Göttingen. Institut für Holzbiologie und Holztechnologie, Göttingen: 90-96.

\title{
Acknowledgements
}

The authors acknowledge the valuable comments by the reviewers Dr. K. Hollenstein and Dr. G. Jungmeier.

\author{
Authors \\ FRANK WERNER, Dipl. Natw. ETH, Eidgenössische Materialprüfungs- \\ und Forschungsanstalt (EMPA), Überlandstrasse 129, $\mathrm{CH}-8600$ \\ Dübendorf; \\ HANS-JORG ALTHAUS, Dipl. Ing. Werkst. ETH, Eidgenössische Material- \\ prüfungs- und Forschungsanstalt (EMPA), Überlandstrasse 129, \\ $\mathrm{CH}-8600$ Dübendorf; \\ Dr. KLAUS RICHIER, Dipl. Holzwirt, Eidgenössische Materialprüfungs- \\ und Forschungsanstalt (EMPA), Überlandstrasse 129, $\mathrm{CH}-8600$ \\ Dübendorf.
}

